\title{
Mind Maps: Useful Schematic Tool For Organizing And Integrating Concepts Of Complex Patient Care In The Clinic And Classroom
}

\author{
Genevieve Pinto Zipp, Seton Hall University, USA \\ Cathy Maher, Seton Hall University, USA \\ Anthony V. D’Antoni, Touro College of Osteopathic Medicine, USA
}

\begin{abstract}
Academicians are always trying to answer the question, "What is the most effective way to teach?" Finding the answer to this question is no easy task but recognizing that each teachable moment must be shaped based upon the learner, task, and the environment enable the academician to consider viable teaching strategies that would promote the learning goals. The purposes of this paper are first, to describe one teaching strategy "Mind Mapping Learning Technique (MMLT)"; second, to provide an understanding of how the MMLT is used to promote critical thinking skills in graduate students; and finally, to assess students perceptions regarding the use of the mind mapping learning technique as a tool to enable them to better organize, prioritize, and integrate material presented in a course.
\end{abstract}

Keywords: Mind mapping, critical thinking, and teaching strategy

\section{INTRODUCTION}

n recent years, many health care professions have advanced the entry-level degree required to practice (Cottrell, 2000; Glicken, 2002; Rothstein, 1998; Threlkeld et al., 1999). This phenomenon has resulted in more contact hours devoted to the curriculum, with a concomitant increase in the number, diversity, and complexity of courses offered (Threlkeld et al., 1999). Within these expanded curriculums more time is now available for the development of student's critical thinking skills. Academicians must seize these teachable moments and advance student critical thinking skills; however, the question still remains as to what learning (teaching) strategies best promotes critical thinking (Taconis, Ferguson-Hessler, \& Broekkamp, 2001; Willingham, 2007).

The "theory of inquiry" proposed by John Dewey and Schon's notion of "reflective practices" in which purposeful thinking and inquiry turns experiences into deep and meaningful learning provides a framework for the development of critical thinking ${ }^{1}$. Critical thinking is a metacognitive, nonlinear process of purposeful judgment that includes self-directed learning and self-assessment (Bodner, 1986; Daley et al., 1999). Metacognition is the knowledge (i.e. awareness) of one's cognitive processes and the efficient use of this self-awareness to these cognitive processes for the monitoring of one's own thinking and learning. A learning strategy is a thinking tool that a student can use to actively acquire information; some examples include mnemonics, charts, or maps (Gage \& Berliner, 1998).

As educators, our role of guiding the student learning experience requires that we understand the learner characteristics and the differences between the adult and child learner. Since health care professional students are adult learners, their learning can be based on the conceptual framework of the constructivist (assimilation) learning

\footnotetext{
${ }^{1}$ Moon J. Reflection in learning and Professional Development: Theory and Practice. London: Stylus, 1999.
} 
theory, which states that in order for meaningful learning (learning with understanding) to occur, learners must link new information with existing information. Figure 1 depicts the bottom up approach to learning associated with the constructivists' theory and provides the theoretical basis for the use of many learning strategies including the mind map learning technique explored here.

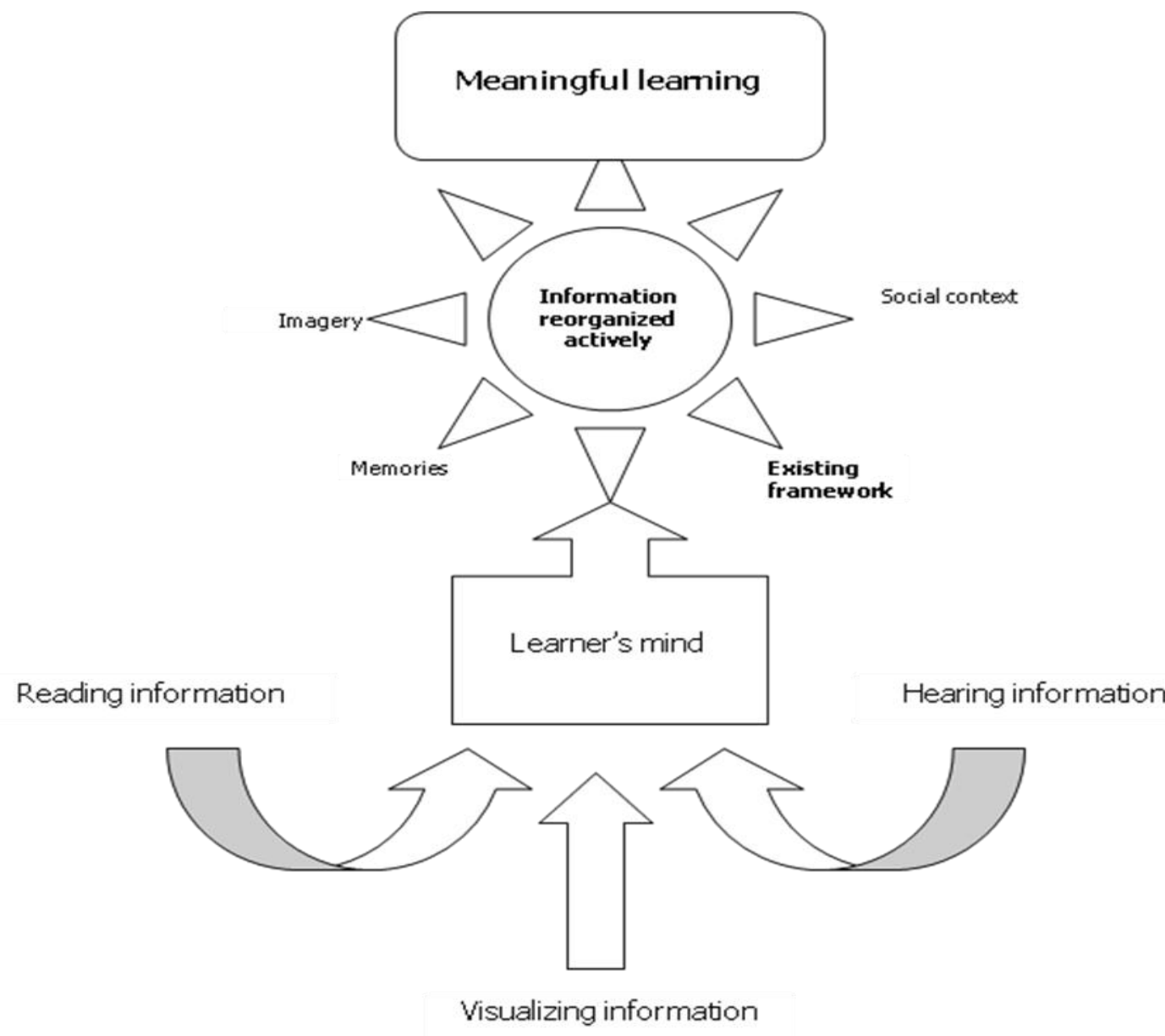

\section{Figure 1. Theoretical assumptions that underlie constructivist theory using a bottom-up approach. Adapted from Ausubel (1978).}

As educators, we cannot teach students to think, but we should be creating learning experiences that will enable students to think and developed ideas using a bottom up approach where rich experiences turn into meaningful learning. Our obligation to our students is to help them turn the wheels of their mind with ever increasing power and clarity as they grow and learn. ${ }^{2}$ Willingham (2007) stated that critical thinking occurs when a student possesses both domain knowledge and the capacity to penetrate beyond the surface structure of a problem to recognize how the problem can be solved. Educators must engage in the utilization of diverse learning/teaching strategies for the promotion of meaningful learning experiences. Several learning strategies which have been used to promote critical thinking include mnemonics, traditional hierarchical note taking, flow charts, scientograms,

\footnotetext{
2 Bridges E, Hallinger P. Implementing Problem-Based Learning. Eugene OR: Educational Resources Information Center, University of Oregon, 1995;3.
} 
concept maps (Novak \& Gowin, 1984) and mind maps (Buzan \& Buzan, 1993). In the traditional hierarchical note taking technique used predominately by students the approach to learning is linear, whereby the student outlines information into categories in a superior-to-inferior and left-to-right spatial pattern. Conversely, the mind map learning technique is an example of a non-linear approach to learning that forces the learner to think curvilinearly using visuospatial relationships flowing from a central theme to peripheral branches. Similarly, concept maps are illustrations of relationships between concepts and facts which are developed based upon a general idea but result in a specific situation and flow from a top major theme to bottom branches.

Both the mind map and concept map can be used by educators and students to identify the structure of prior knowledge, to organize or present new information, or to assess progress and change. ${ }^{3}$ Figure 2 depicts the relationship between concept maps and mind maps with the primary difference being that the mind maps use a multicolor, multi-pictorial schematic with fewer or no propositions. The mind mapping learning strategy is the focus of this paper and therefore will be discussed in detail.

Figure 2

The relationship between concept maps and mind maps

\begin{tabular}{|c|c|}
\hline Concept Map & Mind Map \\
\hline$\underline{\text { Design }}$ & $\underline{\text { Design }}$ \\
\hline Top to bottom & $\overline{\text { Central }} \mathrm{t}$ to peripheral \\
\hline Unicolor & Multicolor \\
\hline No pictures & Multi pictures \\
\hline Many propositions & Few or no propositions \\
\hline Purpose & Purpose \\
\hline Promotes critical thinking by establishing nonlinear & Promotes critical thinking by establishing nonlinear \\
\hline Relationships between concepts & relationship between concepts and enhances recall of \\
\hline & information through the use of dynamic colors and pictures \\
\hline
\end{tabular}

\section{HOW TO CONSTRUCT A MIND MAP}

According to Buzan and Buzan, ${ }^{4}$ a mind map should be drawn on blank paper that is larger than standard 8 $1 / 2$ by 11 inch paper. The rationale behind using larger unlined paper is to allow the student to break away from the boundaries inherent in standard size paper and thus propagate creativity. Once suitable paper is obtained, a medium for drawing the mind map is necessary - namely, colored pens or pencils. The student begins by drawing an image in the center of the paper that reflects the central theme, or topic, of the mind map. This central image allows the student 360 degrees of freedom to develop the mind map. Next, the student would draw the main branches with key words extending from the central image and these branches represent the different categories relevant to the content of the mind map. From these main branches, relevant sub-branches are created. Each of the branches and subbranches should contain accompanying pictures to aid the student in recalling the information. As more subbranches are created, the student will recognize patterns between key words that should be connected, resulting in the integration of different parts of the mind map. Figure 3 illustrates one type of mind map on the assessment and treatment of stroke from a rehabilitative perspective. The map can be visualized as having four quadrants in a clockwise fashion: quadrant 1 focuses on epidemiology, quadrant 2 on anatomy, quadrant 3 on rehabilitation, and quadrant 4 on history, physical examination, and impairments. Alternately, Figure 4 illustrates the linear nature associated with concept mapping.

${ }^{3}$ Daley BJ, Shaw CR, Balistrien T, et al. Concept maps: a strategy to teach and evaluate critical thinking. J Nurs Educ 1999; $38: 42$.

${ }^{4}$ Buzan, T., \& Buzan, B. (1993). The mind map book. London: BBC Books. 
Figure 3

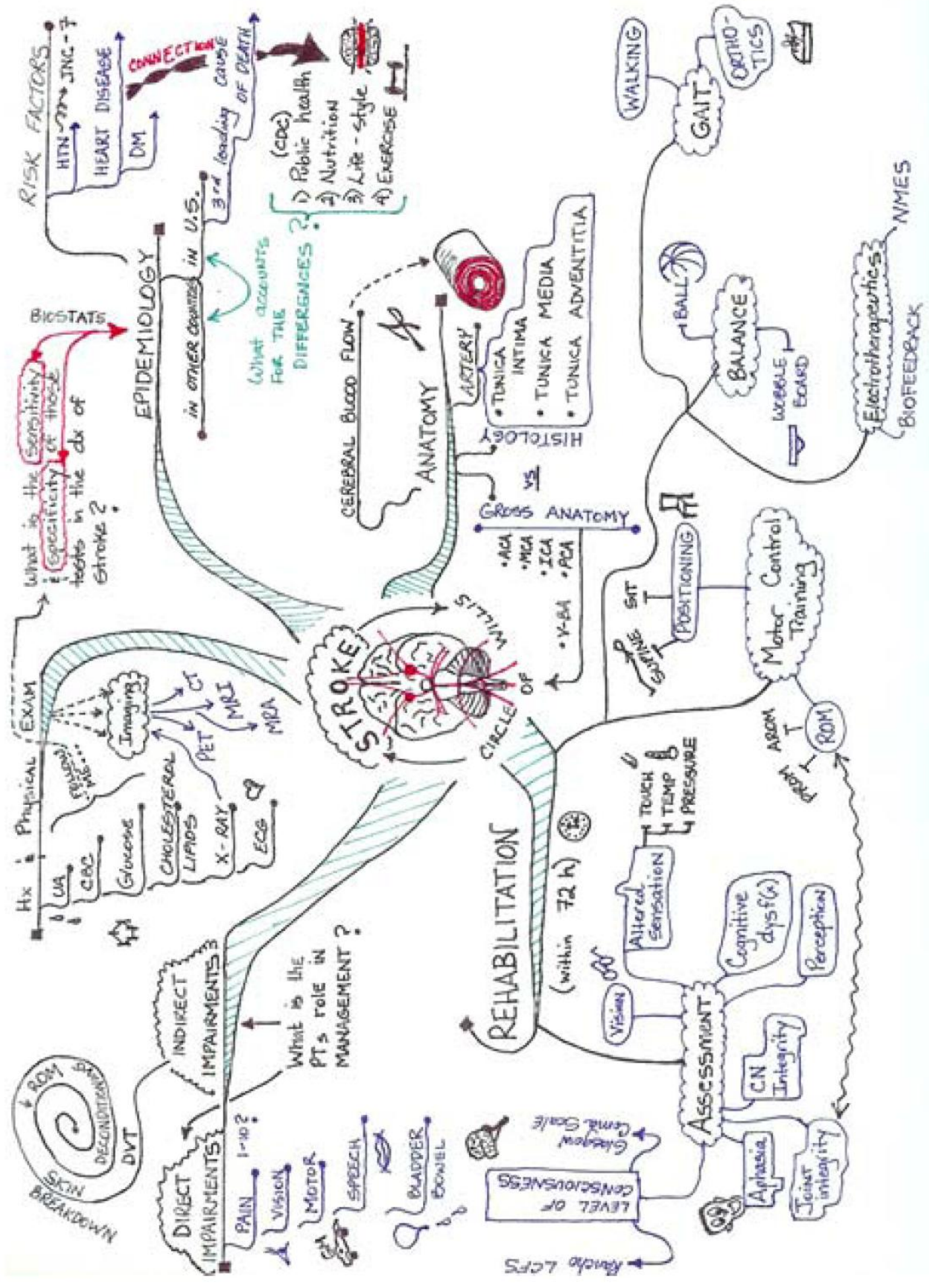


Taken with permission from: D'Antoni, A. V., \& Pinto Zipp, G. (2006). Applications of the mind map learning technique in chiropractic education: A pilot study and literature review. Journal of Chiropractic Humanities, 13, 2-11.

Figure 4

Silverthorn DU. Human physiology: An integrated approach. 2nd ed. Upper Saddle River, NJ: Prentice-Hall; 2001

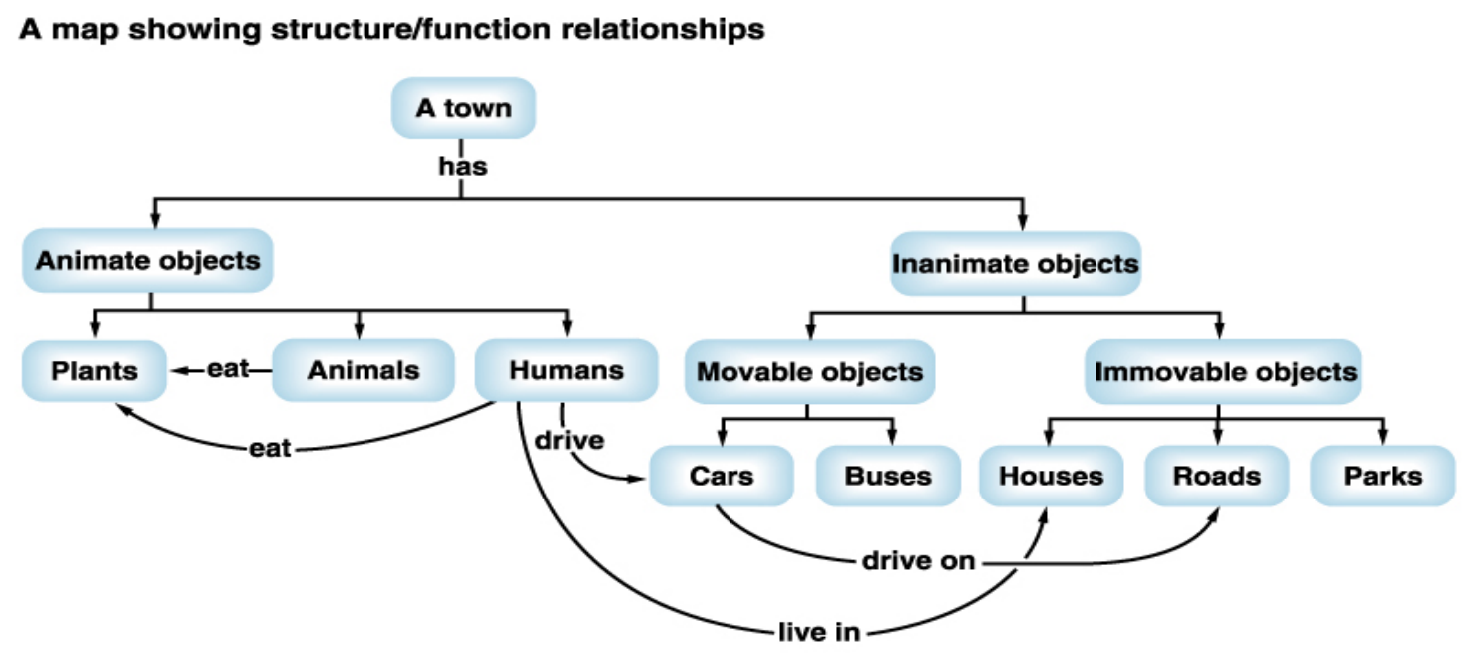

To date limited information is available on the effectiveness of the mind mapping learning technique in the promotion of critical thinking in education however; Irvine (1995) discussed how concept maps (CMs) can be used to promote meaningful learning in nursing students and how CMs can be integrated in nursing curricula. She defined meaningful learning as a process whereby a student links new information with old information, and argued that concept maps facilitate this linking.

Daley et al. (1999) evaluated the usefulness of concept maps in developing critical thinking skills in nursing students. Students in 6 senior clinical groups $(n=54)$ were told to construct concept maps during the first week of class and these same students created 3 maps over the course of the semester. The work of 3 students from each of the 6 groups $(n=18)$ were randomly selected for data analysis and scoring. Scoring criteria were based upon the development of propositions, hierarchy, and cross-links within the maps. A t-test was used to compare mean scores of the first and final concept maps $(\mathrm{p}=.001)$ and the authors concluded that concept maps improved critical thinking in their cohort of nursing students.

Recently, Hill (2006) took a more pragmatic approach by describing how nursing students integrated their daily clinical experiences using concept maps. These students began with a concept map template and created a map as they gained information from their patient assessments throughout the day. They first constructed preconference maps from the data obtained when patients were admitted, and then modified the maps as they obtained more information throughout the day. At the end of the day, they met with nursing instructors to discuss their cases and then created post conference maps. This was a qualitative study and no data were reported. The author concluded that the exercise was meaningful to the students because they were able to visualize changes made to their concept 
maps over time. In addition, the nursing instructors felt that the students demonstrated a stronger understanding of the nursing process as a result of using the maps (Hill, 2006).

To date, Farrand et al. (2002) is the only published work looking at the potential role of mind mapping in medical education. Farrand et al. (2002) investigated whether the mind map learning technique was superior to traditional note taking in both short- and long-term factual recall of written information in medical students. The authors exposed 50 medical students $(\mathrm{n}=50)$ to a 600-word sample of text from Scientific American and then administered 3 short tests based upon the text to the subjects. Recall was only slightly higher but significant in the mind map group after the second test $(\mathrm{p}=.016){ }^{5}$. Comparison of mean scores on the third test (administered 1 week later) revealed that the mind map group had significantly higher factual recall compared to the self-study group $(\mathrm{p}=.013)$.

While, Farrand's work lends support to the potential usefulness of mind maps for the promotion of factual knowledge no data is available to support the hypothesis that mind maps promote critical thinking. Additionally, there has only been one pilot study reported on student's perceptions regarding the use of mind maps ( D'Antoni \& Zipp, 2006). As educators we recognize that student's perceptions are extremely important regarding learning/teaching techniques and therefore can influence the outcome of their effectiveness. Therefore, the focus of

The present research focused on addressing the question, "what are student perceptions of the usefulness of the mind map learning strategy in the promotion of learning?"

\section{RESEARCH QUESTION}

Do students perceive that the mind mapping learning technique enabled them to better organize, prioritize and integrate material presented in a course?

\section{HYPOTHESIS}

Doctor of Physical Therapy students perceive that Mind mapping (MM) helped them better organize, prioritize and integrate material presented in the course when compared to standard note taking.

\section{METHODS}

\section{Subjects}

Doctor of Physical Therapy (DPT) students $(n=21)$ enrolled in a neurorehabilitation course (Management of Neuromuscular Problems) were required to create mind maps based upon assigned readings for six diagnoses.

\section{Procedures}

Students were asked to complete two surveys. Survey one requested demographic information including the following data: Age, Gender, Ethnicity, Overall GPA score and Course grade. Survey two was a post-course survey assessing their perceptions of the usefulness of the mind map learning technique in improving organization, prioritizing and integration of course material. While this survey has not been validated it is used as a standard procedure within the program yearly to gather information on student perceptions specific to this topic.

\section{Study design}

A quantitative post-test exploratory survey design was used to address the research question. The dependent variables were the survey responses regarding perceptions and the independent variable was participation in the mind map group. Survey data analysis included the generation of percent agreement scores.

\footnotetext{
${ }^{5}$ Farrand, P., Hussain, F., \& Hennessy, E. (2002). The efficacy of the 'mind map' study technique. Medical Education, 36, 426431.
} 


\section{RESULTS}

The following student demographic information was noted: $n=21$, age ranged between $24-35$ years old with a mean age of 26.4, there were 9 males and 12 females, their ethnicity included 2 African American, 1 African, 4 Asian American, and 14 Caucasian/Non Hispanic. Their overall GPA ranged from $3.093-3.876$ with a mean of 3.639. Their course GPA ranged from 81.7 (2.9) - 98.89 (3.98) with a mean of 91.53/3.1.

Tables 1 to 3 demonstrate \% agreement using a 5-point Likert scale of student's perceptions on several questions regarding the use of mind mapping in the areas of organizing, prioritizing and integrating information. As noted by the responses presented in Table 1, students overall did not perceive that mind mapping positively assisted them to organize, prioritize or integrate information reviewed.

Table 1. Students' Perception of Mind Mapping in Areas of Organizing, Prioritizing and Integrating (Percent Agreement)

\begin{tabular}{|c|c|c|c|c|c|}
\hline & $\begin{array}{c}\text { Strongly } \\
\text { Agree }\end{array}$ & Agree & Unsure & Disagree & $\begin{array}{l}\text { Strongly } \\
\text { Disagree }\end{array}$ \\
\hline \multicolumn{6}{|l|}{ Organize } \\
\hline Question 5 & 4.8 (n 1) & $33.3(\mathrm{n} 7)$ & 23.8 (n 5) & $19(\mathrm{n} \mathrm{4})$ & $19(\mathrm{n} \mathrm{4)}$ \\
\hline \multicolumn{6}{|l|}{ Prioritize } \\
\hline Question 13 & 0 & $9.5(\mathrm{n} 2)$ & $33.3($ (n 7) & $38.1(\mathrm{n} \mathrm{8)}$ & $19(\mathrm{n} 4)$ \\
\hline \multicolumn{6}{|l|}{ Integrate } \\
\hline Question 6 & 0 & $33.3(n$ 7) & 28.6 (n 6) & $33.3($ (n 7) & 4.8 (n 1) \\
\hline Question 11 & 0 & 0 & 42.9 (n 9) & 42.9 (n 9) & 14.3 (n 3) \\
\hline
\end{tabular}

When looking at students perceptions of the usefulness of mind mapping in various communication situations the responses presented in Table 2 suggest that students on average did not agree that the mind mapping improved communications skills.

Table 2. Student's Perception of Mind Mapping in Areas of Communication (Percent Agreement)

\begin{tabular}{|c|c|c|c|c|c|}
\hline Communication & $\begin{array}{c}\text { Strongly } \\
\text { Agree }\end{array}$ & Agree & Unsure & Disagree & Strongly Disagree \\
\hline $\begin{array}{c}\text { Question } 4 \\
\text { Improved oral } \\
\text { communication } \\
\text { skills }\end{array}$ & 0 & $4.8(\mathrm{n} 1)$ & 9.5 (n 2) & 61.9 (n 13 & $23.8($ n 5) \\
\hline $\begin{array}{c}\text { Question } 7 \\
\text { Communicate with } \\
\text { patients }\end{array}$ & 0 & 9.5 (n 2) & $19(\mathrm{n} 4)$ & 57.1 (n 12 & 14.3 (n 3) \\
\hline $\begin{array}{l}\text { Question } 8 \\
\text { Communicate with } \\
\text { rehabilitation } \\
\text { specialist }\end{array}$ & 4.8 (n 1$)$ & 0 & $33.3(\mathrm{n} 7)$ & 47.6 (n 10) & 14.3 (n 3) \\
\hline $\begin{array}{c}\text { Question } 12 \\
\text { Sharing information } \\
\text { with classmates }\end{array}$ & 0 & 4.8 (n 1) & $33.3(\mathrm{n} 7)$ & 47.6 (n 10) & 14.3 (n 3) \\
\hline
\end{tabular}

Student percent agreement noted in Table 3 again on average did not positively support mind mapping in the development and retention of student knowledge. 
Table 3. Students' Perception of Mind Mapping in Areas of Knowledge (Percent Agreement)

\begin{tabular}{cccccc}
\hline Knowledge & $\begin{array}{c}\text { Strongly } \\
\text { Agree }\end{array}$ & Agree & Unsure & Disagree & $\begin{array}{c}\text { Strongly } \\
\text { Disagree }\end{array}$ \\
\hline $\begin{array}{c}\text { Question 2 } \\
\begin{array}{c}\text { Caluable when } \\
\text { learning concepts }\end{array}\end{array}$ & 0 & $9.5(\mathrm{n} \mathrm{2})$ & $38.1(\mathrm{n} \mathrm{8)}$ & $33.3(\mathrm{n} \mathrm{7)}$ & $19(\mathrm{n} 4)$ \\
\hline $\begin{array}{c}\text { Question } 9 \\
\text { Improved }\end{array}$ & 0 & $28.6(\mathrm{n} \mathrm{6)}$ & $33.3(\mathrm{n} \mathrm{7)}$ & $33.3(\mathrm{n} \mathrm{7)}$ & $4.8(\mathrm{n} \mathrm{1)}$ \\
$\begin{array}{c}\text { understanding of } \\
\text { topic }\end{array}$ & & & & & \\
\hline $\begin{array}{c}\text { Question 10 } \\
\text { Improved retention } \\
\text { of material }\end{array}$ & 0 & $23.8(\mathrm{n} \mathrm{5)}$ & $33.3(\mathrm{n} \mathrm{7)}$ & $19.0(\mathrm{n} \mathrm{4)}$ & $23.8(\mathrm{n} \mathrm{5)}$ \\
\hline
\end{tabular}

When reviewing responses to the surveys open ended questions the following were noted;

- $\quad$ Mind mapping encouraged us to read and outline the chapters, good self study

- $\quad$ Forced me to read the chapter thoroughly, sit down and basically study long before exams

- $\quad$ It helped organized information and good to outline

- $\quad$ Made me actually go through the chapters and keep up on my reading

- I liked the fact that it made me open up the neuro book and truly examine the chapter in a timely efficient manner

- $\quad$ Mind mapping is not my learning style

- $\quad$ I don't think it helped with retention of material

- $\quad$ Not my type of learning, but I'm sure it would help if I spent more time on them

- $\quad$ Not really utilized it during studying since it is not my way of learning

- $\quad$ They were unorganized for my style of learning and after doing them I never looked back at them

\section{RESULTS}

The data from this pilot project suggest that DPT students did not perceive that the mind map learning technique (MMLT) enabled them to better organize, prioritize and integrate material presented in the course. They also perceived that mind mapping was not effective in knowledge development and communication development.

\section{CONCLUSION}

The data obtained from this pilot study on students' perceptions alone does not offer support for the use of the mind mapping learning technique (MMLT) in promoting organization, prioritization and integration of course material in this DPT educational curriculum. However, these findings do not negate the usefulness of mind mapping as a learning tool as the data represents only a small sample of students' perceptions. In order to fully address if mind mapping is effective in organizing, prioritizing and integrating material which fosters the development of critical thinking skills, further work is needed to explore pre/post changes in overall GPA and course GPA as these are objective markers of the development of critical thinking skills. Additional markers of the strategies' usefulness in the development of critical thinking in students may include: the use of standardized critical thinking assessment tools such as pre post measures on the Health Sciences Reasoning Test (HSRT), pre /post knowledge based testing, and obtaining an actual score for the created mind maps.

Finally, based upon several of the student's comments with regard to mind mapping measuring the learning styles of the learners using a tool such as the Gregorc Style Delineator would be an appropriate area for further investigation as a students learning style or preference in learning may influence the usefulness of a 
learning/teaching strategy. Clearly, for an academician finding the right learning strategy is no easy task but recognizing that each teachable moment must be shaped based upon the learner, task and the environment enables the academician to consider viable teaching strategies that would promote the learning goals.

\section{AUTHOR INFORMATION}

Genevieve Pinto Zipp PT, EdD is Chair of the Department of Graduate Programs in Health Sciences at Seton Hall University and holds the academic rank of Associate Professor. She earned her BS in Physical Therapy from UMDNJ, New Jersey, MeD and EdD from Teachers College Columbia University, New York. For over 20 years Dr. Zipp has been active in the areas of professional and post professional graduate education, physical therapy clinical practice, movement science and teaching and learning research and management.

Dr. Cathy Maher DPT, is an assistant professor in the Department of Physical Therapy at Seton Hall University. She received her physical therapy degree of Columbia University, New York and her clinical doctoral degree from Seton Hall University, New Jersey. She has been practicing clinically and teaching for over 20 years. Currently, her areas of speciality practice include neuro rehabilitation, geriatric and prosthetics and orthotics. Dr. Maher is a certified geriatric clinical specialist.

Dr. Anthony V. D'Antoni is Course Director of Preventive Medicine and Public Health at Touro College of Osteopathic Medicine in New York City. He holds a MS degree in bacteriology from Wagner College and two BS degrees, one in biology and the other in human biology from Seton Hall University and National University of Health Sciences, respectively. He is a candidate for a PhD degree in Health Sciences at Seton Hall University's School of Health and Medical Sciences, and also holds a DC degree. Dr. D'Antoni's doctoral work focuses on the use of mind mapping to promote critical thinking in medical students.

\section{REFERENCES}

1. Bellezza, F. S. (1983). The spatial arrangement mnemonic. Journal of Educational Psychology, 75, 830837 .

2. Bodner, G. M. (1986). Constructivism: A theory of knowledge. Journal of Chemical Education, 63, 873878.

3. Bridges E, Hallinger P. Implementing Problem-Based Learning. Eugene OR: Educational Resources Information Center, University of Oregon, 1995; 3.

4. Buzan, T., \& Buzan, B. (1993). The mind map book. London: BBC Books.

5. Cottrell, R. P. (2000). COTA education and professional development: A historical review. American Journal of Occupational Therapy, 54, 407-412.

6. Daley, B. J., Shaw, C. R., Balistrieri, T., Glasenapp, K., \& Piacentine, L. (1999). Concept maps: A strategy to teach and evaluate critical thinking. Journal of Nursing Education, 38, 42-47.

7. Day, J. C., \& Bellezza, F. S. (1983). The relation between visual imagery mediators and recall. Memory \& Cognition, 11, 251-257.

8. D'Antoni, A. V., \& Pinto Zipp, G. (2006). Applications of the mind map learning technique in chiropractic education: A pilot study and literature review. Journal of Chiropractic Humanities, 13, 2-11.

9. Farrand, P., Hussain, F., \& Hennessy, E. (2002). The efficacy of the 'mind map' study technique. Medical Education, 36, 426-431.

10. Gage, N. L., \& Berliner, D. C. (1998). Educational psychology. Boston: Houghton Mifflin Company.

11. Glicken, A. (2002). PA education in an evolving health care system. Journal of the American Academy of Physician Assistants, 15, 16-20, 26.

12. Hill, C. M. (2006). Integrating clinical experiences into the concept mapping process. Nurse Educator, 31 , 36-39.

13. Irvine, L. M. (1995). Can concept mapping be used to promote meaningful learning in nurse education? Journal of Advanced Nursing, 21, 1175-1179.

14. Moon, J. Reflection in learning and Professional Development: Theory and Practice. London: Stylus, 1999.

15. Novak, J. D., \& Gowin, D. B. (1984). Learning how to learn. Cambridge: Cambridge University Press. 
16. Rothstein, J. M. (1998). Education at the crossroads: for today's practice, the DPT. Physical Therapy, 78, 358-360.

17. Silverthorn, D. U. (2001). Human physiology: An integrated approach. 2nd ed. Upper Saddle River: Prentice-Hall.

18. Taconis, R., Ferguson-Hessler, M. G. M., \& Broekkamp, H. (2001). Teaching science problem solving: An overview of experimental work. Journal of Research in Science Teaching, 38, 442-468.

19. Threlkeld, A. J., Jensen, G. M., \& Royeen, C. B. (1999). The clinical doctorate: A framework for analysis in physical therapist education. Physical Therapy, 79, 567-581.

20. Willingham, D. T. (2007). Critical thinking: Why is it so hard to teach? American Educator, 31, 8-19.

\section{NOTES}

